(C) 2014

\author{
Мірзаєва М. C., аспірант
}

(науковий керівник - доктор ветеринарних наук С. М. Кулинич)

Полтавська державна аграрна академія

\title{
РОЗПОВСЮДЖЕННЯ СТОМАТОЛОГІЧНИХ ПАТОЛОГІЙ У СОБАК В УМОВАХ ВЕТЕРИНАРНИХ КЛІНІК МІСТА ПОЛТАВА
}

\section{Рецензент - доктор ветеринарних наук, професор І. В. Яценко}

\begin{abstract}
У роботі подано результати аналізу звітної документації щзодо розповсюдження стоматологічних захворювань в умовах ветеринарних клінік міста Полтава за період 2011-2013 років. Враховано нозоологічні форми прояву патологї у собак та породу. Доведено, щзо стоматологічні патології у собак $\epsilon$ досить поширеними - їх частка становить 21,11\% від хірургічних захворювань. Отримані дані засвідчують необхідність удосконалення та доповнення існуючих методів профілактики й лікування захворювань ротової порожнини у собак.
\end{abstract}

Ключові слова: стоматологічні хвороби, собака, порода, форма прояву.

Постановка проблеми. Захворювання ротової порожнини у собак $є$ досить поширеними [1]. Відомо, що за стоматологічних хвороб бактерії та їх токсини можуть проникати в суміжні ділянки - пазухи носа, середнє вухо та інші органи, спричиняючи їх запалення. Хвороби ротової порожнини займають перше місце серед хвороб шкіри, серцево-судинної системи, органів слуху та зору [2]. Саме тому доцільно проводити дослідження розповсюдження стоматологічних патологій у собак.

Аналіз основних досліджень і публікацій, у яких започатковано розв'язання проблеми. Значне поширення хвороб ротової порожнини обумовлене багатьма причинами, зокрема, переважна більшість дослідників виділяє наступні: низький рівень ветеринарно-стоматологічної допомоги, годівля тварин не властивими для них продуктами (іжа зі столу господаря із значним вмістом цукру та солі), низька якість корму [3-6].

C породи собак, які схильні до захворювань зубів та оточуючих тканин. Це обумовлено анатомічною будовою щелеп - внаслідок їх зменшення слабшають функції, що призводить до хвороб ротової порожнини. На першому місці за поширенням хвороб ротової порожнини знаходяться дрібні породи собак. У них поширеність цих захворювань становить 70-85\% тварин. Рідше стоматологічні хвороби зустрічаються у середніх порід (65-70\% випадків); у великих близько 45-50 \% [7].
Нині за рахунок збільшення кількості карликових порід собак (йоркширські тер'єри, тойтер'єри, чихуахуа, карликові пуделі) збільшилася кількість запальних захворювань пародонта, таких як хронічний генералізований катаральний гінгівіт (ХГКГ) та хронічний генералізований пародонтит (ХГП) [8].

Мета дослідження: на основі 3'ясування поширення стоматологічної патології у собак обгрунтувати актуальність, значимість та доцільність ії подальшого дослідження.

Завдання дослідження: визначити розповсюдження стоматологічних патологій у собак різних порід у ветеринарних клініках м. Полтава.

Матеріали і методи. Дослідження проведено на базі п'яти ветеринарних клінік м. Полтава: «Рижий кіт», Полтавська міська державна лікарня ветеринарної медицини Жовтневого та Київського районів, «Біоцентр», а також «Ветсервіс» за період із 2011 по 2013 рік. На підставі аналізу матеріалів статистичної звітності (а саме Журналу реєстрації хворих тварин форми № 1-вет щодо розповсюдження хірургічної патології, зокрема, хвороб органів ротової порожнини) нами були проведені дослідження стоматологічних патологій, які з них частіше діагностують, а також форми їх прояву залежно від породи та віку.

Підрахунок проводили як у структурі патології - показники зазначені в дужках, - так і за кожного окремого захворювання: гінгівіт (Г), пародонтит (Пт), із аномалій зубного прикусу враховували персистенцію молочних зубів (ПМЗ), пародонтоз (Пз), карієс (К).

Результати досліджень. За результатами звітної документації встановлено, що із 5119 обстежених клінічно хворих собак найчастіше хірургічну патологію діагностували у клініці «Рижий кіт» - 392 собаки, що становить $30,03 \%$, рідше в умовах лікарні Жовтневого району - 279 собак (29,00 \%), не на багато менше діагностували у лікарні Київського району - 276 тварин (28,02\%). У ветеринарній клініці «Біоцентр» 253 собаки, що становить 25,22 \% хірургічної патології. Найрідше господарі хворих тварин зверта- 


\section{СТОРІНКА МОЛОДОГО ВЧЕНОГО}

лися до клініки «Ветсервіс»: за цей період зареєстровано 268 собак (31,01\%) (табл. 1).

\section{1. Поширення хірургічних патологій у собак в умовах ветеринарних клінік м. Полтава} за 2011-2013 pp.

\begin{tabular}{|c|c|c|c|}
\hline \multirow{2}{*}{ Клініки } & \multirow{2}{*}{$\begin{array}{c}\text { Кількість } \\
\text { обстежених } \\
\text { собак }\end{array}$} & \multicolumn{2}{|c|}{$\begin{array}{c}\text { Хірургічна } \\
\text { патологія собак }\end{array}$} \\
\cline { 3 - 4 } & кількість & $\%$ \\
\hline «Рижий кіт» & 1305 & 392 & 30,03 \\
\hline Жовтневий р-н & 962 & 279 & 29,00 \\
\hline Київський р-н & 985 & 276 & 28,02 \\
\hline «Біоцентр» & 1003 & 253 & 25,22 \\
\hline «Ветсервіс» & 864 & 268 & 31,01 \\
\hline Усього & 5119 & 1468 & 28,67 \\
\hline
\end{tabular}

На базі ветеринарної клініки «Рижий кіт» діагностували хірургічні хвороби (табл. 2) сечостатевих органів, загальна частка патології 29,39 \% (в структурі патології - 28,57 \%); встановлено, що патологія черевної порожнини становить $28,18 \%$, тобто 24,23 \% від загальної частки зареєстрованих захворювань; стоматологічні патології становили 26,12\% (20,66 \%); у ділянці голови $24,49 \%(15,56 \%)$ та в ділянці тазу $22,51 \%$ (10,98\%) припадає загалом на частку цієї патології.

У лікарні Жовтневого району також частіше діагностували патології сечостатевих органів $19,16 \%(26,16 \%)$ у загальній частині даної патології; стоматологічні захворювання - 21,61\% (24,01\%); черевної порожнини 18,69\% (22,58 \%) загальна частка від цієї патології; в ділянці голови 18,07 \% (16,12\%); найменше в ділянці тазу - 16,24\% (11,13\%) загальна частка від цієї патології.

У лікарні Київського району хвороби черевної порожнини становили 21,37 \% (26,08\%); сечостатевих органів 16,79\% (23,19\%) - загальна частка від цієї патології; зі стоматологічними захворюваннями діагностовано 18,74\% (21,03\%); у ділянці голови - 18,90 \% (17,02\%) загальна частка від цієї патології, найменше в ділянці тазу $-18,33 \%(12,68 \%)$.

У ветеринарній клініці «Біоцентр» діагностували ті ж патології у такому співвідношенні: хвороби сечостатевих органів - 22,07\% $(31,36 \%)$ загальна частка від цієї патології; в ділянці голови відсоток склав 21,68 \% (20,14 \%); стоматологічні хвороби - 17,41 \% (20,14\%) загальна частка від цієї патології; захворювання черевної порожнини - 14,24 \% (17,91\%); у ділянці тазу $-14,65 \%(10,45 \%)$.

У клініці «Ветсервіс» загальна частка від хвороб черевної порожнини становить 17,52\% (23,32\%); у ділянці тазу - 28,27\% (21,34\%); стоматологічної патології діагностовано $16,12 \%(19,76 \%)$; із хворобами сечостатевих органів - 12,59\% (18,97\%); у ділянці голови $16,86 \%$ (16,61 \%) - загальна частка від даної патології.

Враховуючи те, що нас цікавили стоматологічні патології, ми їм приділили більше уваги (табл. 3). Встановили, що вони найбільш розповсюджені у клініці «Рижий кіт». Частіше всього діагностували $Г-28,98 \%$ (49,38 \%) загальна частка від цієї патології; Пт становить 25,01\% $(19,75 \%)$; ПМЗ - 26,31 \% (18,53 \%) загальна частка від зазначеної патології; K - 20,83\% (6,17\%); Пз становить 18,51\% (6,17\%).

\section{2. Відсоток стоматологічної патології від хірургічної у собак в умовах ветеринарних клінік м. Полтава за 2011-2013 рр.}

\begin{tabular}{|c|c|c|c|c|c|c|c|c|c|c|}
\hline \multirow{3}{*}{ Клініки } & \multicolumn{10}{|c|}{ Хірургічні хвороби } \\
\hline & \multicolumn{2}{|c|}{$\begin{array}{c}\text { сечостатевих } \\
\text { органів }\end{array}$} & \multicolumn{2}{|c|}{$\begin{array}{c}\text { черевної } \\
\text { порожнини }\end{array}$} & \multicolumn{2}{|c|}{$\begin{array}{c}\text { стоматологічні } \\
\text { хвороби }\end{array}$} & \multicolumn{2}{|c|}{$\begin{array}{l}\text { у ділянці } \\
\text { голови }\end{array}$} & \multicolumn{2}{|c|}{$\begin{array}{l}\text { у ділянці } \\
\text { таза }\end{array}$} \\
\hline & $\begin{array}{l}\text { кіль- } \\
\text { кість }\end{array}$ & $\%$ & $\begin{array}{l}\text { кіль- } \\
\text { кість }\end{array}$ & $\%$ & $\begin{array}{l}\text { кіль- } \\
\text { кість }\end{array}$ & $\%$ & $\begin{array}{l}\text { кіль- } \\
\text { кість }\end{array}$ & $\%$ & $\begin{array}{l}\text { кіль- } \\
\text { кість }\end{array}$ & $\%$ \\
\hline «Рижий кіт» & 112 & 29,39 & 95 & 28,18 & 81 & 26,12 & 61 & 24,49 & 43 & 22,51 \\
\hline Жовтневий р-н & 73 & 19,16 & 63 & 18,69 & 67 & 21,61 & 45 & 18,07 & 31 & 16,24 \\
\hline Київський р-н & 64 & 16,79 & 72 & 21,37 & 58 & 18,74 & 47 & 18,90 & 35 & 18,33 \\
\hline «Біоцентр» & 84 & 22,07 & 48 & 14,24 & 54 & 17,41 & 54 & 21,68 & 28 & 14,65 \\
\hline «Ветсервіс» & 48 & 12,59 & 59 & 17,52 & 50 & 16,12 & 42 & 16,86 & 54 & 28,27 \\
\hline Усього & 381 & 100 & 337 & 100 & 310 & 100 & 249 & 100 & 191 & 100 \\
\hline
\end{tabular}




\section{СТОРІНКА МОЛОДОГО ВЧЕНОГО}

У клініці Жовтневого району за цей період Г становить $21,74 \%(44,77 \%)$ - загальна частка від цієї патології; Пт - 20,31 \% (19,40 \%); ПМЗ $19,29 \%(16,47 \%)$; загальна частка від Пз $25,92 \%$ (10,44 \%); К становить 25,02 \% (8,92\%).

Встановлено, що в клініці Київського району зареєстровано Г 18,12\% (43,12\%) - загальна частка від цієї патології; ПМЗ - 21,08\% (20,68\%); Пт - 15,62 \% (17,24\%); Пз становить $22,25 \%$ (10,34 \%); на загальну частку від К припадає 20,83 \% (8,62 \%). Рідше стоматологічні патології реєстрували на клініці «Біоцентр». Найбільше було Г - 16,68 \% (42,59 \%); менше Пт - 18,75\% (22,22 \%); ПМ3 - 17,54 \% (18,51\%) загальна частка від даної патології; Пз - 18,51 \% $(9,25 \%)$; К становить $16,66 \%$ (7,43 \%). Найменше зареєстровано хвороб у клініці «Ветсервіс»: Г 14,49 \% (40,00 \%) - становить загальну частку від цієї патології; Пт - 20,31 \% (26,00 \%); ПМЗ становить $15,78 \%$ (18,00\%); Пз дорівнює
$14,81 \%$ (8,00 \%); на загальну частку від патології К становить $16,66 \%$ (8,00 \%).

Серед стоматологічних патологій у залежності від порід розповсюдженими були (табл. 4): у такс $-13,95 \%(52,95 \%)$ - загальна частка від цієї патології, діагностували хронічний генералізований катаральний гінгівіт (ХГКГ), хронічний генералізований пародонтоз (ХГПз) - 40,00\% $(29,41 \%)$ - загальна частка від цієї патології та поверхневий фісурний карієс (ПФК) - 54,55 \% $(17,64 \%)$. Той-тер'єри $3 \quad$ ХГКГ $-\quad 13,17 \%$ $(41,46 \%)$, гострий локалізований катаральний гінгівіт (ГЛКГ) складає 33,35 \% (36,59 \%), персистенція молочних зубів (ПМЗ) - становить 17,64 \% (21,95 \%). Серед собак породи пудель також діагностовано стоматологічні патології: ХГКГ - 10,85 \% (45,17\%) - загальна частка від цієї патології, хронічний генералізований пародонтит (ХГПт) - 24,48 \% (38,71 \%), ПФК діагностовано у $45,45 \%(16,12 \%)$.

\section{3. Нозоологічні форми стоматологічної патології у собак в умовах ветеринарних клінік м. Полтава за 2011-2013 рр.}

\begin{tabular}{|c|c|c|c|c|c|c|c|c|c|c|}
\hline \multirow{3}{*}{ Клініки } & \multicolumn{10}{|c|}{ Стоматологічні патології } \\
\hline & \multicolumn{2}{|l|}{$\Gamma$} & \multicolumn{2}{|c|}{ Пт } & \multicolumn{2}{|c|}{ ПМЗ } & \multicolumn{2}{|l|}{ Пз } & \multicolumn{2}{|l|}{ K } \\
\hline & кількість & $\%$ & кількість & $\%$ & кількість & $\%$ & кількість & $\%$ & кількість & $\%$ \\
\hline «Рижий кіт» & 40 & 28,98 & 16 & 25,01 & 15 & 26,31 & 5 & 18,51 & 5 & 20,83 \\
\hline Жовтневий р-н & 30 & 21,74 & 13 & 20,31 & 11 & 19,29 & 7 & 25,92 & 6 & 25,02 \\
\hline Київський р-н & 25 & 18,12 & 10 & 15,62 & 12 & 21,08 & 6 & 22,25 & 5 & 20,83 \\
\hline «Біоцентр» & 23 & 16,68 & 12 & 18,75 & 10 & 17,54 & 5 & 18,51 & 4 & 16,66 \\
\hline «Ветсервіс» & 20 & 14,49 & 13 & 20,31 & 9 & 15,78 & 4 & 14,81 & 4 & 16,66 \\
\hline Усього & 138 & 100 & 64 & 100 & 57 & 100 & 27 & 100 & 24 & 100 \\
\hline
\end{tabular}

4. Розповсюдження стоматологічної патології у собак різних порід в умовах ветеринарних клінік м. Полтава за 2011-2013 рр.

\begin{tabular}{|c|c|c|c|c|c|c|c|c|c|c|c|c|}
\hline \multirow{3}{*}{ Породи } & \multicolumn{12}{|c|}{ Стоматологічні патології } \\
\hline & \multicolumn{2}{|c|}{ ХГКГ } & \multicolumn{2}{|c|}{ ГЛКГ } & \multicolumn{2}{|c|}{ ХГПт } & \multicolumn{2}{|c|}{ ПМЗ } & \multicolumn{2}{|c|}{ ХГПз } & \multicolumn{2}{|c|}{ ПФК } \\
\hline & $\begin{array}{l}\text { кіль- } \\
\text { кість }\end{array}$ & $\%$ & $\begin{array}{l}\text { кіль- } \\
\text { кість }\end{array}$ & $\%$ & $\begin{array}{l}\text { кіль- } \\
\text { кість }\end{array}$ & $\%$ & $\begin{array}{l}\text { кіль- } \\
\text { кість }\end{array}$ & $\%$ & $\begin{array}{l}\text { кіль- } \\
\text { кість }\end{array}$ & $\%$ & $\begin{array}{l}\text { кіль- } \\
\text { кість }\end{array}$ & $\%$ \\
\hline Такса & 18 & 13,95 & - & - & - & - & - & - & 10 & 40,00 & 6 & 54,55 \\
\hline Той-тер'єр & 17 & 13,17 & 15 & 33,35 & - & - & 9 & 17,64 & - & - & - & - \\
\hline Пудель & 14 & 10,85 & - & - & 12 & 24,48 & - & - & - & - & 5 & 45,45 \\
\hline Чихуахуа & 16 & 12,43 & - & - & 5 & 10,20 & 6 & 11,78 & - & - & - & - \\
\hline Кокер & 15 & 11,62 & - & - & 10 & 20,40 & - & - & 7 & 28,00 & - & - \\
\hline Йорк & 39 & 30,23 & - & - & - & - & 11 & 21,56 & - & - & - & - \\
\hline Мопс & - & - & 9 & 20,00 & 7 & 14,28 & 8 & 15,68 & - & - & - & - \\
\hline Пекінес & - & - & 13 & 28,88 & 15 & 30,64 & 11 & 21,56 & 8 & 32,00 & - & - \\
\hline Безпорідні & 10 & 7,75 & 8 & 17,77 & - & - & 6 & 11,78 & - & - & - & - \\
\hline Усього & 129 & 100 & 45 & 100 & 49 & 100 & 51 & 100 & 25 & 100 & 11 & 100 \\
\hline
\end{tabular}




\section{СТОРІНКА МОЛОДОГО ВЧЕНОГО}

ХГКГ у чихуахуа - 12,43 \% (59,25 \%), ПМЗ становить $11,78 \%$ (22,24\%), ХГПт - 10,20\% (18,51\%) загальна частка від досліджуваної патології. У собак породи кокер ХГКГ - 11,62 \% (46,88 \%), ХГПт - 20,40 \% (31,25\%), ХГПз діагностували у $28,00 \%$ (21,87 \%). Йоркширські тер'єри хворіли на ХГКГ 30,23\% (78,00\%) та на ПМЗ - 21,56 \% $(22,00 \%)$ - загальна частка від цієї патології. ГЛКГ у породи мопс становить $20,00 \%$ (37,51\%), ХГПт - 14,28\% (29,16\%), ПМЗ становить $15,68 \%$ (33,33 \%) загальна частка від цієї патології. Крім того господарі приводили до клінік собак породи пекінес - у цих порід стоматологічні хвороби діагностували найчастіше. ГЛКГ $28,88 \%$ (27,65\%), ХГПт становить $30,64 \%$ (31,94\%), ПМЗ становить 21,56\% (23,41\%), ХГПз - 32,00\% (17,01\%) загальна частка від цієї патології. У безпорідних собак також діагностовано стоматологічні патології. ХГКГ 7,75 \% (41,66 \%) припадає на загальну частку від цієї патології, ГЛКГ - 17,77 \% (33,34 \%), ПМ3 становить $11,78 \%(25,00 \%)$.

Висновки: 1. В умовах п'яти ветеринарних клінік м. Полтава за період із 2011 по 2013 рік

\section{БІБЛІОГРАФІЯ}

1. Васильева М. Б. Воспалительные заболевания пародонта у собак: автореф. дис. ... канд. вет. наук. 16.00.05 - ветеринарная хирургия / М. Б. Васильева. - СПб., 2009. - 21 с.

2. Грохольский $A . П$. Зубные отложения и их влияние на ткани пародонта : автореф. дис. ... канд. мед. наук. 14.01.22 - стоматологія - К., 1965. - $26 \mathrm{c}$.

3. Петренко О.Ф. До питання про хвороби зубів у собак і котів // Ветеринарна медицина України. - 1998. - №10. - С. 16-18.

4. Петренко О. Ф., Чухно В. С. Стоматологічні втручання у собак (ендодонтія, реставрації зубів, лікування прогенії різців) / Методичні рекомендації. - К., 2007. - 20 с. було обстежено 5119 собак, з яких із хірургічною патологією виявлено 1468 (28,67 \%) тварин.

2. Стоматологічні захворювання діагностували у 310 собак $(21,11 \%)$. Серед них найчастіше діагностували гінгівіт (у 138 собак), пародонтит (у 64 собак), аномалію зубного прикусу (персистенція молочних зубів) - 57 собак, пародонтоз (у 27 собак), у 24 собак карієс.

3. За нозоологічними формами стоматологічних патологій діагностовано: хронічний генералізований катаральний гінгівіт у 129 собак, у 51 собаки персистенцію молочних зубів, 49 собак хворіли на пародонтит, гострий локалізований катаральний гінгівіт виявлено у 45 собак, хронічний генералізований пародонтоз - у 25 собак і в 11 собак - поверхневий фісурний карієс.

4. Отримані результати доводять, що стоматологічні патології розповсюджені, завдають збитків і турбот власникам тварин, що доводить актуальність цієї теми. Для іії вирішення необхідно більш швидко, якісно й патогенетично обгрунтовано проводити діагностичні та лікувальні заходи для одужання собак із даною хворобою.

5. Самойленко А. В. Сучасні аспекти етіології, патогенезу та лікування різних клінічних варіантів генералізованого пародонтиту : автореф. дис. ... доктора мед. наук. 14.01.22 - стоматологія Одеса, 2003. - 34 с.

6. Фролов В. В. Распространение заболеваний зубочелюстной системы у собак // Ветеринария Поволжья, 2002. - № 3. - С. 33-34.

7. Фролов $B . B$. Болезни зубов и полости рта у собак. - М. : Аквариум Бук, 2003. - 96 с.

8. Чухно В. С. Методи реставрації зубів у собак // Четверта наукова конференція професорсько-викладацького складу і аспірантів НДІ ВМ, ЯБП АПК: Тези доповідей. - К. : Національний аграрний університет, 3-4 березня 2005. - С. 99. 